\title{
Bioavailability of Heavy Metals (Cd, Cr, Ni, Pb) to French Marigold (Tagetes patula) in relation to Soil properties
}

\author{
Singh SK* and Biswojit Biswal* \\ Department of Soil Science and Agricultural Chemistry, Banaras Hindu University, India
}

Submission: March 27, 2018; Published: April 16, 2018

*Corresponding author: Department of Soil Science and Agricultural Chemistry, Institute of Agricultural Sciences, Banaras Hindu University, Varanasi-221 005(India), Email: sksingh_1965@rediffmail.com

\begin{abstract}
After one month of incubation of soils with $\mathrm{Cd}, \mathrm{Ni}, \mathrm{Pb}$ and $\mathrm{Cr}$ at the rate of $5,10,20$ and $30 \mathrm{mg} / \mathrm{kg}$, it was found that maximum DTPA extractable concentration was $8.78 \mathrm{mg} / \mathrm{kg}$ (Sewage sludge), $0.483 \mathrm{mg} / \mathrm{kg}$ (Alkali soil), $18.59 \mathrm{mg} / \mathrm{kg}$ (Sewage irrigated soil) and 20.54mg/kg (Sandy Soil), respectively. Coorelation study showed a highly positive significant coorelation of $\mathrm{Cd}$ with organic carbon $\left(\mathrm{r}=0.883^{* *}\right), \mathrm{Pb}$ with clay $\left(\mathrm{r}=0.726^{*}\right)$, $\mathrm{Cr}$ with sand $\left(\mathrm{r}=0.789^{*}\right)$ and significant negative coorelation of $\mathrm{Ni}_{\text {ith }} \mathrm{CaCO}_{3}\left(\mathrm{r}=0.813^{*}\right)$. Marigold crop could not survive in sandy soil and Alkali soil might be due to the $\mathrm{Cr}$ toxicity and adverse physical condition, respectively. Highest uptake of $\mathrm{Cd}$ was noticed in red soil while that of $\mathrm{Cr}$ and $\mathrm{Ni}$ is sewage irrigated soil. Lead was less bio available. Concentration of $\mathrm{Cr}$ and $\mathrm{Ni}$ was recorded in flowers where as $\mathrm{Cd}$ and $\mathrm{Pb}$ were not detectable. The $\mathrm{pH}$ had a significant negative coorelation $\left(\mathrm{r}=-0.741^{*}\right)$ with $\mathrm{Cd}$ uptake whereas a significant positive coorelation of organic carbon $\left(\mathrm{r}=0.882^{* *}\right)$ was noted with $\mathrm{Cr}$ uptake. It was further observed that dry matter yield had positive coorelation with uptake and negative coorelation with content of heavy metas in plants. The DTPA extractable Ni was almost not detectable in post harvest soils
\end{abstract}

Keywords: Heavy metals; Contaminated soil; Phytoremediation; Bioavailability; Alluvial soil; Alkali soil; River clay soil; Sandy soil; Black soil; Garden soil; Sewage irrigated soil

\section{Introduction}

Heavy metals are among one of the pollutants which pose severe threats to environment and their occurrence in soil indicates the presence of natural or anthropogenic sources. Soil physico-chemical properties are adversely affected by high concentration of heavy metal, rendering contaminated soil unsuitable for crop production [1,2]. The heavy metals may be transported through soil to reach ground waters or may be taken up by plants .It has been observed that only a small fraction of the total soil concentration of metals is potentially toxic [3]. This fraction is known as the mobile or bioavailable fraction which is of concern due to its potential leaching in to ground water and/or entering the food chain through plants [4]. Impact of heavy metals contamination on agricultural soils depends not only on type and amount of contaminants but also on soil properties. Variation in soil properties may significantly influence the distribution as well as the bioavailability of heavy metals to plants [5]. Keeping the above facts in view, a study was initiated during 2008-09 to assess the impact of various soil properties on bioavailability of heavy metals $(\mathrm{Cd}, \mathrm{Cr}, \mathrm{Ni}, \mathrm{Pb})$ taking French marigold as a test crop .

\section{Methods}

To conduct pot experiment, nine soils viz: Alluvial soil, Alkali soil, River clay soil, Sandy soil, Black soil, Garden soil,
Sewage irrigated soil and Sewage sludge were collected from different locations of Varanasi and Mirzapur districts .Soil properties indicated a variation in $\mathrm{pH} 4.7$ to 9.5 , EC 0.10 to 2.59 $\mathrm{dSm}^{-1}$, OC 0.03 to $14.24 \%, \mathrm{CaCO}_{3} 0.5$ to $10.5 \%$ and clay 8.79 to $44.56 \%$. Pots lined with polythene sheet were filled with $4 \mathrm{~kg}$ of air dried soils. Soils in the pots were treated with the dominant heavy metals present in sewage sludge such as $\mathrm{Cd}, \mathrm{Ni}, \mathrm{Pb}$ and $\mathrm{Cr}$ at the rate of $5,10,20$ and $30 \mathrm{mg} / \mathrm{kg}$, respectively. The soils were ir rigated to field capacity and kept in the net house for one month to allow added metals to equilibrate before planting. Two plants of French Marigold (Tagetes patula) Variety: Honey Comb was planted. Nine soils were taken as treatments and replicated thrice in a Completely Randomized Block Design. Fertilizer dose of $\mathrm{N}, \mathrm{P}_{2} \mathrm{O}_{5}, \mathrm{~K}_{2} \mathrm{O}$ was applied at the rate of $100,45,45 \mathrm{mg} / \mathrm{kg}$ soil. Plants were harvested at flowering stage i.e. 90 days after transplanting. Plant samples were washed sequentially with $0.2 \%$ soap solution, $0.1 \mathrm{~N} \mathrm{HCl}$ and finally with distilled water Dried and ground plant samples were subjected for analysis. Soil properties were analysed following standard analytical procedures. Soils after one month of incubation were extracted by DTPA as per procedure developed by Lindsay \& Norvell [6] and plant samples were digested in di acid. The content of $\mathrm{Cd}, \mathrm{Ni}, \mathrm{Pb}$ and $\mathrm{Cr}$ in soil extract and plant digest was determined using atomic absorption spectrophotometer (UNICAM-969). 
Results

It is evident (Table 1) that $\mathrm{Cd}, \mathrm{Cr}, \mathrm{Ni}$ and $\mathrm{Pb}$ concentration in metals treated soils after one month of incubation ranged between 2.44 (river clay soil) to 8.78 (sewage sludge), 0.32 (sewage sludge) to 20.54 (sandy soil), 0.023 (river clay soil) to 0.483 (Alkali soil) and 6.73 (sewage sludge) to $18.59 \mathrm{mg} /$ $\mathrm{kg}$ (sewage irrigated soil), respectively. Cadmium availability showed positive and significant correlation with organic matter $\left(\mathrm{r}=0.883^{* *}\right)$. It appears that organic matter likely to promote the extractability of $\mathrm{Cd}$ in soil by supplying soluble organic complexing agents which could reduce the Cd fixation in soil [2]. The Ni extractability in treated soils showed a significant negative correlation $\left(\mathrm{r}=0.813^{*}\right)$ with $\mathrm{CaCO}_{3}$ which could be due to precipitation of $\mathrm{CaCO}_{3}$ that bind the $\mathrm{Ni}$ in unavailable fractions [7].

Table 1: Heavy metals status $(\mathrm{mg} / \mathrm{kg})$ in soils.

\begin{tabular}{|c|c|c|c|c|c|c|c|c|}
\hline \multirow{2}{*}{ Soil Types } & \multicolumn{9}{|c|}{ Initial Soil } & \multicolumn{4}{c|}{ Metals Treated Soil } \\
\cline { 2 - 9 } & $\mathbf{C d}$ & $\mathbf{C r}$ & $\mathbf{N i}$ & $\mathbf{P b}$ & $\mathbf{C d}$ & $\mathbf{C r}$ & $\mathbf{N i}$ & $\mathbf{P b}$ \\
\hline Red soil & $*$ ND & 0.009 & 0.364 & 2.34 & 3.22 & 1.41 & 0.407 & 12.08 \\
\hline Black soil & 0.285 & ND & 0.255 & 2.24 & 5.31 & 1.4 & 0.449 & 15.64 \\
\hline Alluvial soil & ND & 0.027 & ND & 2.63 & 3.88 & 2.39 & 0.196 & 9.76 \\
\hline $\begin{array}{c}\text { River clay } \\
\text { soil }\end{array}$ & 0.205 & 0.58 & 0.05 & 3.01 & 2.44 & 2.28 & 0.023 & 10.11 \\
\hline $\begin{array}{c}\text { Sewage irrig. } \\
\text { soil }\end{array}$ & 0.644 & 0.055 & 0.39 & 12.16 & 5.81 & 0.72 & 0.273 & 18.59 \\
\hline Garden soil & ND & 0.072 & ND & 4.75 & 4.22 & 0.37 & 0.388 & 12.17 \\
\hline $\begin{array}{c}\text { Sewage } \\
\text { sludge }\end{array}$ & 7.53 & 0.237 & 0.066 & 8.41 & 8.78 & 0.32 & 0.058 & 6.73 \\
\hline Sandy soil & ND & 0.043 & 0.368 & 0.7 & 5.75 & 20.54 & 0.138 & 12.74 \\
\hline Alkali soil & ND & 0.109 & ND & 3.24 & 3.52 & 3.12 & 0.483 & 15.56 \\
\hline
\end{tabular}

*Not Detectable

As regards to the heavy metals content in initial soil (Table 1), maximum content of DTPA extractable $\mathrm{Cd}, \mathrm{Cr}, \mathrm{Ni}$ and $\mathrm{Pb}$ was noticed in Sewage sludge $(7.53 \mathrm{mg} / \mathrm{kg})$, River clay soil $(0.58 \mathrm{mg} /$ $\mathrm{kg})$, Sandy soil $(0.36 \mathrm{mg} / \mathrm{kg})$, and sewage irrigated soil $(12.16 \mathrm{mg} / \mathrm{kg})$, respectively. All the heavy metals under study were present in sewage sludge and sewage irrigated soils. Plant of marigold could not survive in Alkali soil due to high $\mathrm{pH}$ and adverse physical condition and in Sandy soil because of very high concentration of $\mathrm{Cr}(20.54 \mathrm{mg} / \mathrm{kg})$ recorded after treatment of heavy metals which was used for growing crop.

The concentration of heavy metals in dry matter (Table 2) indicates that maximum content of $\mathrm{Cd}, \mathrm{Cr}, \mathrm{Ni}$ and $\mathrm{Pb}$ was in Red soil (158.58mg/kg), Alluvial soil $(22.41 \mathrm{mg} / \mathrm{kg})$, Sewage irrigated soil $(29.64 \mathrm{mg} / \mathrm{kg})$, Black soil $(12.25 \mathrm{mg} /$ $\mathrm{kg}$ ), respectively. Lead concentration was not detectable in plants grown in Red soil, Alluvial soil, River clay soil and Garden soil. The Cd concentration in plants showed negative and significant correlation $\left(\mathrm{r}=-0.81^{*}\right)$ with $\mathrm{CaCO}_{3}$ content of Table 2: Dry matter yield, concentration and uptake of heavy metals. soil. The concentration of $\mathrm{Cr}$ and $\mathrm{Ni}$ in flower ranged from 6.76 to 10.80 and 12.52 to $29.86 \mathrm{mg} / \mathrm{kg}$, respectively across the soils whereas concentration of $\mathrm{Cd}$ and $\mathrm{Pb}$ in flowers was not detectable.

The uptake pattern of French marigold grown in different soils revealed (Table 2) that maximum uptake of $\mathrm{Cd}, \mathrm{Cr}, \mathrm{Ni}$ and $\mathrm{Pb}$ was found in Red soil $(0.683 \mathrm{mg} / \mathrm{kg})$, Sewage irrigated soil $(0.084 \mathrm{mg} / \mathrm{kg})$, Sewage irrigated soil $(0.14 \mathrm{mg} / \mathrm{kg})$ and Black soil $(0.061 \mathrm{mg} / \mathrm{kg})$, respectively. A significant negative correlation was recorded with soil $\mathrm{pH}\left(\mathrm{r}=-0.741^{*}\right)$ and $\mathrm{CaCO}_{3}$ $\left(\mathrm{r}=-0.804^{*}\right)$ content of soil to that of uptake of $\mathrm{Cd}$ by plants whereas highly significant positive correlation was noticed with Organic carbon $\left(\mathrm{r}=0.882^{* *}\right)$ and Sand $\left(\mathrm{r}=0.783^{*}\right)$ content of soil to that of $\mathrm{Cr}$ uptake by plants. It has also been reported that $\mathrm{Cd}$ uptake had a negative correlation with soil $\mathrm{pH}$ [8] and Cr uptake had a significant positive correlation with organic matter content of soil $[9,10]$.

\begin{tabular}{|c|c|c|c|c|c|c|c|c|c|}
\hline \multirow{2}{*}{ Soil Types } & \multirow{2}{*}{$\begin{array}{c}\text { Dry Matter } \\
\text { (g/pot) }\end{array}$} & \multicolumn{3}{|c|}{ Concentration(mg/kg) } & \multicolumn{4}{c|}{ Uptake(mg/pot) } \\
\cline { 3 - 12 } & $\mathbf{C d}$ & $\mathbf{C r}$ & $\mathbf{N i}$ & $\mathbf{P b}$ & $\mathbf{C d}$ & $\mathbf{C r}$ & $\mathbf{N i}$ & $\mathbf{P b}$ \\
\hline Red soil & 4.3 & 158.5 & 10.43 & 14.29 & $* \mathrm{ND}$ & 0.683 & 0.045 & 0.062 & ND \\
\hline Black soil & 5 & 56.85 & 16.19 & 2.61 & 12.25 & 0.284 & 0.081 & 0.013 & 0.061 \\
\hline Alluvial soil & 3.36 & 57.37 & 22.41 & 3.06 & ND & 0.192 & 0.075 & 0.01 & ND \\
\hline $\begin{array}{c}\text { River clay } \\
\text { soil }\end{array}$ & 2.37 & ND & 20.21 & 2.91 & ND & ND & 0.048 & 0.007 & ND \\
\hline
\end{tabular}




\section{Trends in Technical \& Scientific Research}

\begin{tabular}{|c|c|c|c|c|c|c|c|c|c|}
\hline $\begin{array}{c}\text { Sewage } \\
\text { irrig. soil }\end{array}$ & 4.73 & 5.84 & 17.9 & 29.64 & 3.12 & 0.03 & 0.084 & 0.14 & 0.015 \\
\hline Garden soil & 4.83 & 62.32 & 17.17 & 21.04 & ND & 0.303 & 0.083 & 0.102 & ND \\
\hline $\begin{array}{c}\text { Sewage } \\
\text { sludge }\end{array}$ & 3.87 & 21.67 & 19.97 & 28.81 & 8.72 & 0.084 & 0.077 & 0.111 & 0.034 \\
\hline Sem \pm & 0.14 & 1.26 & 0.45 & 0.31 & 0.08 & 0.004 & 0.001 & 0.001 & - \\
\hline C D (p=0.05) & 0.43 & 3.85 & 1.37 & 0.95 & 0.24 & 0.013 & 0.004 & 0.114 & 0.001 \\
\hline
\end{tabular}

Plants grown in heavy metals treated soils showed decline in growth and biomass yield as compared to control (untreated) but Swage treated soil and River clay soil did not have any adverse effect of heavy metals treatment on biomass yield. This may be due to the fixation of heavy metals in these soils. The content of most of the heavy metals showed negative relation with content and uptake of other metals. It was noticed that with increase in dry matter yield, the uptake of heavy metals by plants was found to increase but the concentration of metals in plant decreased.

The DTPA extractable Ni content of post harvest soil was not detectable except in Sewage irrigated soil $(0.26 \mathrm{mg} / \mathrm{kg})$ and Sewage sludge $(0.45 \mathrm{mg} / \mathrm{kg})$.This might be due to high content of $\mathrm{CaCO}_{3}$ in these soils which precipitated and bound $\mathrm{Ni}$ in unavailable fractions. A negative significant correlation ( $\mathrm{r}=$ $-0.813^{*}$ ) between $\mathrm{CaCO}_{3}$ and $\mathrm{Ni}$ availability of soil corroborate this result.

\section{Conclusion}

It is concluded that soil properties significantly influence the distribution and bioavailability of heavy metals $(\mathrm{Cd}, \mathrm{Cr}, \mathrm{Ni}, \mathrm{Pb})$ in soil and thus concept of bioavailability in determining the critical content of heavy metals should be adopted for all soils.

\section{References}

1. Hernandez-Allica J, Garbiscu C, Barrutia O, Becerril JM (2007) EDTAinduced heavy metal accumulation and phytotoxicity in cardoon plants. Environmental Experimental Botany 60(1): 26-32.
2. Udom BE, Mbagwa JSC, Adesodun JK, Agbim NN (2004) Distributions of zinc, copper, cadmium, and lead in a tropical ultisol after long term disposal of sewage sludge. Environ Int 30(4): 467-470.

3. Delft H (1997) Methodology for determination of heavy metals standards for soil. Research Report prepared for Ministry of Housing, Spatial Planning and Environment Directorate General for Environment Protection pp. 180.

4. Cook N, Hendershot WH (1996) The problems of establishing ecologically based soil quality criteria: The case of Lead. Canadian Journal of Soil Science 76(3): 335-342.

5. Barrancikova G, Makovnikova J (2003) The influence of soil humic acid quality of sorption and mobility of heavy metals. Plant Soil Environ 12: 565-571.

6. Lindsay WL, Norvell WA (1978) Development of a DTPA soil test for zinc, iron, manganese and copper. Soil Science Society American Journal 42: 421-428.

7. Bose S, Bhattacharya AK (2008) Heavy metal accumulation in wheat plant grown in soil amended with industrial sludge. Chemosphere 70(7): 1264-1272.

8. Singh SP, Nayyer VK (2001) Influence of lime on Nickel availability to plants and its toxic level in cowpea. Journal of Research, Punjab Agricultural University 38(1/2): 10-13.

9. Wang B, Xie Z, Chen J, Jiang J, Su Q (2008) Effect of field application of phosphate fertilizers on the availability and uptake of lead, zinc and cadmium by cabbage (Brassica chinensis L.) in a mining tailing contaminated soil. J Environ Sci (China) 20(9): 1109-1117.

10. Sinha S, Gupta AK, Kavita Bhatt (2007) Uptake and translocation of metals in Fenugreek grown on soil amended with tannery sludge: involvement of antioxidants. Ecotoxicol Environ Saf 67(2): 267-277.

\section{Your next submission with Juniper Publishers will reach you the below assets}

- Quality Editorial service

- Swift Peer Review

- Reprints availability

- E-prints Service

- Manuscript Podcast for convenient understanding

- Global attainment for your research

- Manuscript accessibility in different formats

( Pdf, E-pub, Full Text, Audio)

- Unceasing customer service

Track the below URL for one-step submission https://juniperpublishers.com/online-submission.php 